\title{
Mites and leaf domatia: no evidence of mutualism in Coffea arabica plants
}

\author{
Gustavo Quevedo Romero ${ }^{1,6,7}$, Rodrigo Damasco Daud ${ }^{2}$, Adriana Trevizoli Salomão ${ }^{3}$, \\ Luiz Fernando Martins ${ }^{4}$, Reinaldo José Fazzio' Feres ${ }^{5,6}$ \& Woodruff Whitman Benson ${ }^{1}$ \\ ${ }^{1}$ Departamento de Biologia Animal, Instituto de Biologia, Universidade Estadual de Campinas - UNICAMP, \\ CEP 13083-970, Campinas, SP, Brazil \\ ${ }^{2}$ Departamento de Biologia Geral, Departamento de Ecologia, Instituto de Ciências Biológicas, \\ Universidade Federal de Goiás - UFG, Campus II, CP 131, CEP 74001-970, Goiania, GO, Brazil \\ ${ }^{3}$ Programa de Pós-graduação em Ecologia, Instituto de Biologia, \\ Universidade Estadual de Campinas - UNICAMP, CP 6109, CEP 13083-970, Campinas, SP, Brazil \\ ${ }^{4}$ Centro de Pesquisas e Desenvolvimento Leopoldo Américo Miguez de Mello, Av. Horácio de Macedo, \\ n. 950, Prédio 11, CEP 21941-915, Cidade Universitária, Rio de Janeiro, RJ, Brazil \\ ${ }^{5}$ Departamento de Zoologia e Botânica, Instituto de Biociências, Letras e Ciências Exatas, \\ Universidade Estadual Paulista - UNESP, CEP 15054-000, São José do Rio Preto, SP, Brazil \\ ${ }^{6}$ Pesquisadores bolsistas do $\mathrm{CNPq}$ \\ ${ }^{7}$ Corresponding author: Gustavo Quevedo Romero,e-mail: gq_romero@yahoo.com.br
}

ROMERO, G.Q., DAUD, R.D., SALOMÃO, A.T., MARTINS, L.F., FERES, R.J.F. \& BENSON, W.W. Mites and leaf domatia: no evidence of mutualism in Coffea arabica plants. Biota Neotrop. 11(1): http://www. biotaneotropica.org.br/v11n1/en/abstract?article+bn00311012011.

Abstract: We conducted experiments by blocking off pit-like domatia from old and new leaves of Coffea arabica
L., using tiny resin drops, to investigate the role of domatia on i) mite abundance at the community level and on
ii) leaf damages. More than $77 \%$ of the mites collected were predators, whereas 19 and $3.3 \%$ were omnivores
and phytophages, respectively. Domatia blockage treatment had no influence either on mite abundances or
leaf damages. However, predatory and omnivorous mites were more abundant on new than on the old leaves;
phytophagous mites occurred at very low density and occupied only plants having open domatia. The absence
of mutualism between mites and C. arabica probably occurred because the entrances of domatia were too small
and did not enable the entry of fitoseid predators in these structures. Keywords: mite-plant interactions, mite community, space limitation, Atlantic Rain Forest, mutualism breakdown.

ROMERO, G.Q., DAUD, R.D., SALOMÃO, A.T., MARTINS, L.F., FERES, R.J.F. \& BENSON, W.W. Ácaros e domácias foliares: sem evidências de mutualismo em plantas de Coffea arabica. Biota Neotrop. 11(1): http:// www.biotaneotropica.org.br/v11n1/pt/abstract?article+bn00311012011.

Resumo: Domácias são pequenas estruturas presentes na junção entre as nervuras principal e secundárias das folhas de muitas espécies de plantas, que podem mediar interações mutualísticas entre ácaros e plantas. Em experimento, nós bloqueamos as domácias em formato de covas de folhas novas e velhas de Coffea arabica L. com gotas de resina, a fim de investigar o seu papel i) na abundância de ácaros na comunidade e ii) nos danos foliares. Mais de $77 \%$ dos ácaros coletados são predadores, enquanto 19 e 3,3\% são onívoros e fitófagos, respectivamente. Não houve influência do bloqueio das domácias tanto na abundância quanto nos danos foliares. Entretanto, os ácaros predadores e micófagos foram mais abundantes nas folhas novas do que nas velhas; os ácaros fitófagos ocorreram em pequena densidade e ocuparam somente as plantas com domácias abertas. A ausência de mutualismo entre os ácaros e plantas de C. arabica pode ter ocorrido porque as entradas das domácias analisadas eram muito pequenas, não permitindo a entrada dos predadores fitoseídeos nessas estruturas.

Palavras-chave: interações entre ácaros e plantas, comunidade de ácaros, limitação de espaço, Mata Atlântica, ruptura de mutualismo. 


\section{Introduction}

Leaf domatia or acarodomatia are tiny structures present in the vein axils on the underside of leaves of many Angiospermae species. Their most common shapes are pit (i.e., invaginations of leaf surface that reach the mesophyll), pocket (cavities beneath expanded veins), dense hair-tufts, or an association between hair-tufts and pits or pockets (O'Dowd \& Willson 1989, Nishida et al. 2005). The main inhabitants of leaf domatia are mites, especially predators of the families Phytoseiidae and Stigmaeidae; fungivores of the groups Tarsonemidae, Winterschmidtiidae and Oribatida are also typically common (revised in Romero \& Benson 2005). Whereas up to 52\% of the plant species from some temperate forests bear leaf domatia, presence of such structures is rare elsewhere, particularly in tropical forests (revised in Romero \& Benson 2005).

Leaf domatia have no apparent physiological function (Nakamura et al. 2002). However, they can mediate mutualistic interactions between plants and mites, as fungivores and predators (Walter 1996, Romero \& Benson 2005). In this relationship, the mites are benefited by finding shelter against their natural enemies inside domatia (Faraji et al. 2000a, b, Roda et al. 2000, Norton et al. 2001). For example, Norton et al. (2001) have found that leaf domatia of Vitis riparia Michx. protected the mycophage Orthotydeus lambi (Baker) and the predator Amblyseius andersoni (Chant) against the predatory bug Orius insidiosus (Say) and coccinellid beetles. Although studies have suggested that domatia may also decrease mite desiccation (e.g., O'Dowd \& Willson 1989), to date no study has empirically corroborated this assumption (Grostal \& O'Dowd 1994, Romero \& Benson 2005). In return, the beneficial mites can decrease plant damages caused by pathogenic fungi (Norton et al. 2000) or phytophagous mites (Agrawal et al. 2000, Romero \& Benson 2004). As an alternative hypothesis, Romero \& Benson (2004) suggested that leaf domatia could buffer predator-prey oscillations by providing refuge for prey (typically phytophages); phytophages protected in domatia may disperse onto the leaf surface in a continuous flux providing a reliable food source for predators, thus minimizing local extinction.

The commercial coffee plant, Coffea arabica L. (Rubiaceae), is originated from Ethiopia but cultivated worldwide. Leaves of this crop species bear pit-like domatia (see Figure 1a in Romero \& Benson 2005) that can shelter several mite species (O'Dowd 1994, Mineiro et al. 2008), most of them being predators (O'Dowd 1994). Recent studies have reported that leaf domatia of $C$. arabica can improve survivorship of predatory mites (e.g. Matos et al. 2006). However, to date no study has evaluated the influence of coffee domatia on the mite community or even has tested the role of domatia as mediators of mite-plant mutualism (i.e., a biotic plant defense) on Coffea plants. Here we conducted experiments by blocking off coffee leaf domatia with tiny resin drops to investigate the role of domatia on i) mite abundance at the community level and on ii) mite-plant mutualism. The main questions addressed were: 1) Do leaf domatia in C. arabica increase beneficial mite abundance? 2) Are leaves with blocked domatia more damaged by fungi and/or phytophagous mites?

\section{Methods}

\section{Study area and system}

This study was done in the Santa Genebra Municipal Reserve (SGMR) $\left(22^{\circ} 48^{\prime}-50^{\prime} \mathrm{S} ; 4^{\circ} 06^{\prime}-07^{\prime} \mathrm{W}\right)$, an area of 251.8 ha with altitudes varying from 585 to $616 \mathrm{~m}$, located in Campinas, São Paulo State, Southeastern Brazil. The climate is Cwa type according to Köppen's classification, characterized by a dry and cool winter and a wet and hot summer; the mean annual rainfall is ca. 1380 $\mathrm{mm}$, and mean temperatures vary from $17.4^{\circ} \mathrm{C}$ (winter) to $22.7^{\circ} \mathrm{C}$ (summer) (Mello et al. 1994). The reserve is covered mainly by semideciduous mesophytic forest (85\%) and also by a swamp forest (15\%) (Leitão-Filho 1995).

The plant species Coffea arabica L. grows wild as a shrub or small tree in the deeply shaded forest understory (Coste 1992), but it also grows well in moderately shaded environments (Shimber et al. 2002). Presently, is one of the most common shrub species inhabiting understories of SGMR (Grombone-Guaratini 1999, Martins \& Rodrigues 2005), where it was introduced in the second half of the $19^{\text {th }}$ century (from 1852 to 1880 ) by coffee farmers who used the forest as a natural greenhouse to maintain the plantlets under shade before the plantation, so as to simulate their natural environment (forest understory) (Bernacci \& Leitão-Filho 1996, Serrão 2002). Since then, this plant species has grown naturally in the reserve and the success in establishment probably took place because of frugivorous birds that have dispersed their seeds throughout the forest (Grombone-Guaratini 1999).

\section{General experimental design}

To verify whether leaf domatia mediate mutualism between mites and commercial Coffea plants, we randomly selected and numbered 40 saplings growing naturally in the SGMR, along a narrow track that cross the reserve. A half of these plants had all the domatia of every leaf closed off using droplets of sticky Tanglefoot ${ }^{\circledR}$ resin (Grand Rapids, MI, USA) applied with a syringe needle (experimental). The reminder were used as controls, receiving the same amount of resin in the form of droplets placed to the side of each domatium $(0.5-2.0 \mathrm{~cm}$ apart) to control for the influence of the resin on mite community. This procedure was successfully used in other studies (e.g. Romero \& Benson 2004). The control and experimental plants were interspersed to achieve a systematic design (see Hurlbert 1984), and a distance of ca. 5-30 m separated the saplings. The new leaves produced after the beginning of the experiment received resin according to each treatment. The resin caused no damage to the coffee leaves. No mites were found stuck in the resin during the experiment. The experiment duration (4-7 months) was enough for mites to colonize the leaves that had their domatia blocked (Romero \& Benson 2004).

In the beginning of the experiment (September 2-3, 2004) we randomly chose five new, expanded leaves from every sapling; they were individualized by attaching a thin, differently colored wire to each petiole. In December 16, 2004, three additional new, expanded leaves were chosen and individualized as above. These saplings were 0.5-1.5 m tall, each bearing 7-49 and 9-69 leaves during the first and second dates, respectively. The leaves selected for the experiment were used to obtain both mite abundance and leaf damage measurements.

\section{Mite abundance}

On April 27, 2005 the marked leaves from the first date (hereafter "old leaves") and second date (hereafter "new leaves") were kindly collected and kept individually in plastic bags inside a polypropylene box at $10{ }^{\circ} \mathrm{C}$ for 1 hour to decrease mite movements, and then they were transferred to a refrigerator at ca. $6{ }^{\circ} \mathrm{C}$ until examined. Mites were counted under a stereoscopic microscope, collected from both sides (upper and lower) of the old and new leaves for later identification according to their taxonomic group and guild designation, and then kept in polyethylene vials containing ethanol at $70 \%$. Since the blockage procedure may have killed some mites located inside domatia, to maintain comparability between counts in the two treatments, mites inside domatia from control plants were not counted. Similar procedures were also used in previous studies (e.g. Romero \& Benson 2004). In laboratory all the mites were mounted 
on slides in Hoyer's medium (Moraes \& Flecthmann 2008) and identified under light phase contrast microscope. The guilds of the mites were assigned according to Krantz (1978), Walter \& O'Dowd (1992), O'Dowd (1994), and Moraes \& Flecthmann (2008). Voucher specimens are deposited in the mite collection of the Laboratório de Acarologia (DZSJRP) - http://www.splink.cria.org.br, Universidade Estadual Paulista (UNESP, Department of Zoology and Botany), in São José do Rio Preto, São Paulo, Brazil.

To verify whether mites use domatia of Coffea plants, and if they are more abundant inside than outside these structures, on April 27, 2005 we collected 20 additional leaves from saplings other than those used for the experiment. The leaves were stored as above. We counted the total number of mites, mite eggs and exuviae inside and around (radius $=0.5 \mathrm{~cm}$ ) each of 189 domatia under a stereoscopic microscope. The same methods were already used by Romero \& Benson (2004) for similar purposes.

\section{Leaf damage}

The influence of domatia on leaf damages was examined in the same leaves used to determine mite abundance (above). Soon after mite collection, we recorded area removed and number of damages caused by chewers, area and number of spots of fungi, area and number of necrotic patches and number of epiphylls on the upper side of each leaf. We could not identify the agent that caused the necrosis, but this damage is possibly related to those caused by phytophages (Romero \& Benson 2004). In addition, we recorded the proportion of old leaves (marked in the beginning of the experiment; September 2004) that have fallen at the end of the experiment.

The area of leaf damage caused by chewers at the end of the experiment was determined by multiplying the length of the longer and shorter axis of each hole. Products obtained for 40 leaf holes from other plants collected in the same study area were correlated with the hole areas obtained from tracings on graph paper. The product of breadth and length explained $99 \%$ of the variation in hole size in a linear regression model $(\mathrm{P}<0.0001)$; thus we used this model to estimate the area of damages from the experiment. Since few leaves had marks of herbivory caused by chewers before the treatments were applied, we recorded the number and area of the damages at the beginning of the experiment and subtracted these values from those obtained at the end to eliminate the effect of initial damage on the final results. The areas of fungal spots and necrotic patches were estimated using the formula for an ellipse: $A=\varpi(R \times r)$, where $\mathrm{A}=$ patch or spot area, $\mathrm{R}=$ the larger radius and $\mathrm{r}=$ the smaller radius.

\section{Statistical analyses}

The general experimental design was systematic (Hurlbert 1984). To test the influence of domatia blockage and leaf age on mite abundance we used ANOVA, in which domatia blockage (two levels) and leaf age (two levels) were fixed effects. This analysis was run for the total number of predators and omnivorous mites, for the most abundant mite species separately, and for the main guilds (predators and omnivores). The number of mites, mite eggs and mite exuviae were compared inside and outside domatia using paired $t$-test.

To test the influence of domatia blockage and leaf age on the number of epiphylls, number and area of necrosis, as well as damages caused by chewers and fungi we used ANCOVA, in which domatia blockage (two levels) and leaf age (two levels) were fixed effects, and initial number of leaves per plantlet was the covariate. Similar analysis was run to test the influence of domatia removal on the proportion of the old leaves that have fallen until the end of the experiment. Data on mite abundance and leaf damage were $\log (n+1)$ transformed, and data on the proportion of leaves fallen until the end of the experiment were arc-sin squared root transformed to achieve ANOVA assumptions of normality and homogeneity of variances.

\section{Results}

\section{Mite abundance}

Overall, we recorded 179 mites belonging to 16 species in nine families (Table 1). From these species, $77.7 \%$ were predators, whereas 19 and $3.3 \%$ were omnivores and phytophages, respectively. The most common species were the predators Iphiseiodes sp. $(\mathrm{n}=70)$ and Amblyseius herbicolus (Chant) $(\mathrm{n}=35)$, both from

Table 1. Mean and total number of mite species belonging to different guilds (i.e., predadors "Pr", Omnivores "Om" and Phytophages "Ph") on new or old leaves that had ("obstructed") or had not ("control") their domatia obstructed. SE means standard errors.

\begin{tabular}{|c|c|c|c|c|c|c|c|c|c|c|}
\hline \multirow[t]{3}{*}{ Order/Family } & \multirow[t]{3}{*}{ Genus/Species } & \multirow[t]{3}{*}{ Guild } & \multicolumn{4}{|c|}{ New leaves } & \multicolumn{4}{|c|}{ Old leaves } \\
\hline & & & \multicolumn{2}{|c|}{ Control } & \multicolumn{2}{|c|}{ Obstructed } & \multicolumn{2}{|l|}{ Control } & \multicolumn{2}{|c|}{ Obstructed } \\
\hline & & & Mean (SE) & Total & Mean (SE) & Total & Mean (SE) & Total & Mean (SE) & Total \\
\hline Acaridae & Tyrophagus putrecentiae & $\mathrm{Om}$ & $0.03(0.023)$ & 2 & $0.07(0.04)$ & 4 & $0.046(0.02)$ & 3 & $0.025(0.017)$ & 2 \\
\hline Ascidae & Asca sp. & $\operatorname{Pr}$ & - & - & - & - & - & - & $0.014(0.014)$ & 1 \\
\hline \multirow[t]{3}{*}{ Cunaxidae } & Armascirus sp. & $\operatorname{Pr}$ & - & - & - & - & $0.015(0.015)$ & 1 & $0.01(0.01)$ & 1 \\
\hline & Cunaxa sp1. & $\operatorname{Pr}$ & - & - & - & - & $0.015(0.015)$ & 1 & - & - \\
\hline & Cunaxa sp2. & $\operatorname{Pr}$ & - & - & $0.017(0.017)$ & 1 & - & - & - & - \\
\hline Oribatida & unidentified & Om & $0.12(0.05)$ & 5 & $0.09(0.06)$ & 3 & $0.01(0.01)$ & 1 & $0.01(0.01)$ & 1 \\
\hline \multirow[t]{4}{*}{ Phytoseiidae } & Amblyseius hexadens & $\operatorname{Pr}$ & $0.03(0.03)$ & 2 & - & - & - & - & - & - \\
\hline & Amblyseius herbicolus & $\operatorname{Pr}$ & $0.22(0.06)$ & 13 & $0.12(0.05)$ & 7 & $0.07(0.06)$ & 6 & $0.08(0.03)$ & 9 \\
\hline & Iphiseiodes sp. & $\operatorname{Pr}$ & $0.29(0.12)$ & 17 & $0.53(0.16)$ & 26 & $0.12(0.07)$ & 6 & $0.25(0.08)$ & 21 \\
\hline & Immature & $\operatorname{Pr}$ & $0.1(0.04)$ & 6 & $0.09(0.04)$ & 5 & $0.14(0.06)$ & 7 & $0.05(0.02)$ & 4 \\
\hline Stigmaeidae & Agistemus sp. & $\operatorname{Pr}$ & - & - & $0.02(0.02)$ & 1 & - & - & $0.04(0.02)$ & 4 \\
\hline Tarsonemidae & Fungitarsonemus sp. & $\mathrm{Om}$ & $0.05(0.03)$ & 3 & - & - & $0.015(0.015)$ & 1 & $0.01(0.01)$ & 1 \\
\hline Tenuipalpidae & Brevipalpus phoenicis & $\mathrm{Ph}$ & $0.017(0.017)$ & 1 & - & - & - & - & - & - \\
\hline \multirow{4}{*}{ Tydeidae } & Lorryia formosa & $\mathrm{Ph}$ & $0.017(0.017)$ & 1 & $0.03(0.02)$ & 2 & - & - & - & - \\
\hline & Lorryia sp. & $\mathrm{Ph}$ & - & - & - & - & $0.02(0.02)$ & 2 & - & - \\
\hline & Prelorryia sp. & $\operatorname{Om}(?)$ & $0.017(0.017)$ & 1 & - & - & $0.01(0.01)$ & 1 & - & - \\
\hline & Pretydeus sp. & $\operatorname{Om}(?)$ & $0.08(0.08)$ & 5 & - & - & $0.01(0.01)$ & 1 & - & - \\
\hline
\end{tabular}


the family Phytoseiidae, representing 39.1 and $19.5 \%$ of the mites surveyed, respectively. Other predators also recorded were Asca sp. (Ascidae), Amblyseius hexadens Karg (Phytoseiidae), Agistemus sp. (Stigmaeidae), Armascirus sp., and two Cunaxa species (Cunaxidae). The most abundant omnivorous species were two unidentified species belonging to the Oribatida and Acaridae groups, each one representing $5.6 \%$ of the mites surveyed. The reminder omnivores were Tyrophagus putrescentiae (Schrank, 1781) (Acaridae) and Fungitarsonemus sp., Prelorryia sp. and Pretydeus sp. (Tydeidae). Only six phytophagous mites were surveyed [Table 1: Lorryia formosa Cooreman $(\mathrm{n}=3)$, Lorryia $\mathrm{sp} .(\mathrm{n}=2)$ (Tydeidae) and Brevipalpus phoenicis (Geijskes) $(\mathrm{n}=1)$ (Tenuipalpidae)].

Leaf blockage treatment had no apparent influence on mite abundances, and this occurred for mite taxa (Tables 1 and 2) as well as for mite guilds (Figure 1, Table 2). Mites tended to be more abundant on new leaves than on the old ones. Whereas this pattern was observed for unidentified Oribatida, A. herbicolus and Iphiseiodes sp., which were the most dominant species on the Coffea leaves, the reminder species (e.g., unidentified Acaridae) presented no such tendency (Tables 1 and 2). Similarly, predatory and omnivorous mites were more abundant on new than on old leaves (Figure 1, Table 2). The phytophagous mites occurred at very low density and occupied only control plants (Figure 1).

The number of mites inside (mean $\pm 1 \mathrm{SE} ; 0.35 \pm 0.15$ ) and outside domatia $(0.7 \pm 0.26)$ did not differ statistically $(t$-test; $\mathrm{t}=1.05$, $19 \mathrm{df}, \mathrm{P}=0.309)$. Similar results were also obtained for mite eggs

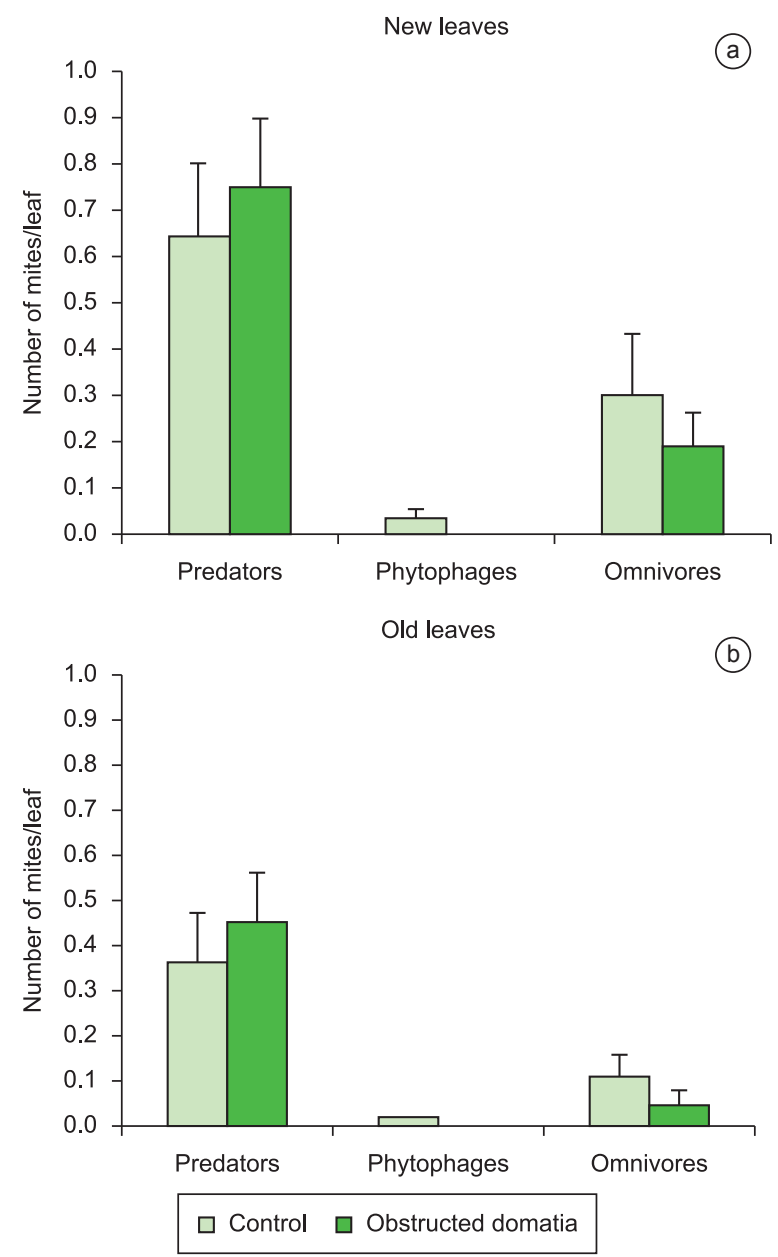

Figure 1. Mean number of predators, phytophages and omnivores on new and old leaves that had their domatia obstructed or treated as control. SE means standard errors. (inside: $0.65 \pm 0.36$; outside: $0.15 \pm 0.11 ; \mathrm{t}=1.27,19 \mathrm{df}, \mathrm{P}=0.220$ ). However, the number of mite exuviae was more than 2 times higher inside domatia $(6.95 \pm 1.2)$ than outside them (3.15 \pm 0.44$)$, with statistically significant difference $(\mathrm{t}=2.84,19 \mathrm{df}, \mathrm{P}=0.010)$.

\section{Leaf damage}

The area of Coffea leaves which was eaten by chewers did not differ between treatments (ANCOVA; $\mathrm{F}_{1,65}=0.97, \mathrm{P}=0.328$ ) and between leaf ages (old vs. new; $\mathrm{F}_{1,65}=0.13, \mathrm{P}=0.714$ ); the interaction term between these factors did not differ statistically $\left(\mathrm{F}_{1,65}=0.02\right.$, $\mathrm{P}=0.446$ ). Similar results were also obtained for number of marks left by chewers; there was no statistical difference between experimental and control leaves $\left(\mathrm{F}_{1,65}=0.329, \mathrm{P}=0.568\right)$, between old and new leaves $\left(\mathrm{F}_{1,65}=0.090, \mathrm{P}=0.765\right)$, and between factors (interactions: $\mathrm{F}_{1,65}=2.78, \mathrm{P}=0.099$ ).

Table 2. ANOVA examining the effects of domatia blockage (treatment) and leaf age on mean number of mite species and guilds (predators and omnivores).

\begin{tabular}{|c|c|c|c|c|c|}
\hline Parameters & $\begin{array}{c}\text { Source of } \\
\text { variation }\end{array}$ & df & $M S$ & $F$ & $P$ \\
\hline
\end{tabular}

Tyrophagus

putrescentiae

$\begin{array}{lrccc}\text { Treatment } & 1 & 0.001145 & 0.08 & 0.782 \\ \text { Leaf age } & 1 & 0.004846 & 0.32 & 0.570 \\ \text { Treat } \times \text { leaf age } & 1 & 0.015459 & 1.04 & 0.312 \\ \text { Error } & 70 & 0.014884 & - & -\end{array}$

Oribatida unidentified

$\begin{array}{lrrcc}\text { Treatment } & 1 & 0.000780 & 0.25 & 0.620 \\ \text { Leaf age } & 1 & 0.017800 & 5.65 & 0.020 \\ \text { Treat } \times \text { leaf age } & 1 & 0.000780 & 0.25 & 0.620 \\ \text { Error } & 76 & 0.003152 & - & -\end{array}$

Amblyseius

herbicolus

Phytoseiidae (immature)

$\begin{array}{lrccc}\text { Treatment } & 1 & 0.004399 & 0.85 & 0.358 \\ \text { Leaf age } & 1 & 0.025717 & 4.99 & 0.028 \\ \text { Treat } \times \text { leaf age } & 1 & 0.011336 & 2.20 & 0.142 \\ \text { Error } & 76 & 0.005156 & - & -\end{array}$

Iphiseiodes sp.

$\begin{array}{lcccc}\text { Treatment } & 1 & 0.040994 & 2.47 & 0.120 \\ \text { Leaf age } & 1 & 0.068664 & 4.14 & 0.045 \\ \text { Treat } \times \text { leaf age } & 1 & 0.000647 & 0.04 & 0.844 \\ \text { Error } & 76 & 0.016573 & - & -\end{array}$

$\begin{array}{lrccc}\text { Treatment } & 1 & 0.004320 & 1.06 & 0.306 \\ \text { Leaf age } & 1 & 0.000434 & 0.11 & 0.745 \\ \text { Treat } \times \text { leaf age } & 1 & 0.001428 & 0.35 & 0.556 \\ \text { Error } & 76 & 0.004077 & - & -\end{array}$

Predators

$\begin{array}{lrccc}\text { Treatment } & 1 & 0.012321 & 0.57 & 0.451 \\ \text { Leaf age } & 1 & 0.100391 & 4.67 & 0.034 \\ \text { Treat } \times \text { leaf age } & 1 & 0.000000 & 0.00 & 0.997 \\ \text { Error } & 70 & 0.021499 & - & -\end{array}$

Omnivores

\begin{tabular}{lrrrc} 
Treatment & 1 & 0.009146 & 1.03 & 0.312 \\
Leaf age & 1 & 0.049971 & 5.66 & 0.020 \\
Treat $\times$ leaf age & 1 & 0.000300 & 0.03 & 0.854 \\
Error & 76 & 0.008835 & - & - \\
\hline
\end{tabular}


Whereas the number of epiphylls, and number and area of fungal spots and necrotic patches did not differ between treatments, most of these types of damages (e.g., area and number of fungal spots and patches of necrosis) were higher on old than new leaves (Figure 2a, e, Table 3). The proportion of old leaves that have fallen until the end of the experiment did not differ between the treatments (ANCOVA; $\left.\mathrm{F}_{1,37}=1.05, \mathrm{P}=0.313\right)$.

\section{Discussion}

Our findings indicate that leaf domatia did not mediate mutualism between mites and Coffea plants in the study area. Despite this, several mite species have been found in association with leaf domatia of C. arabica plants in Australia (O'Dowd 1994), Brazil (Matos et al. 2006, Mineiro et al. 2008), Costa Rica (Vega et al. 2007), and Hawaii, USA (Pemberton \& Turner 1989). In addition, recent studies have showed that coffee domatia improve survival and reproduction of the predatory mite Iphiseiodes zuluagai Denmark \& Muma in southeastern Brazil (e.g. Matos et al. 2004, 2006). These results have been interpreted as evidence for a mutualistic relationship between mites and Coffea plants, mediated by leaf domatia (Matos et al. 2006, Mineiro et al. 2008). However, for a mutualism to occur, evidence on the effects of beneficial mites on plant attributes (e.g., decrease in

Table 3. ANCOVA examining the effects of domatia blockage (treatment) and leaf age on the number and area of damages on Coffea leaves. Total number of leaves per plantlet was used as the covariate.

\begin{tabular}{|c|c|c|c|c|c|}
\hline Parameters & Source of variation & df & $M S$ & $F$ & $P$ \\
\hline \multicolumn{6}{|l|}{ Epiphylls (no.) } \\
\hline & Treatment & 1 & 129.3481 & 0.87 & 0.354 \\
\hline & Leaf age & 1 & 53.5107 & 0.36 & 0.550 \\
\hline & Treat $\times$ Leaf age & 1 & 114.9525 & 0.77 & 0.382 \\
\hline & Covariate & 1 & 43.6955 & 0.29 & 0.589 \\
\hline & Error & 66 & 148.7843 & - & - \\
\hline \multicolumn{6}{|l|}{ Fungi (no.) } \\
\hline & Treatment & 1 & 72.480 & 0.09 & 0.764 \\
\hline & Leaf age & 1 & 6749.599 & 8.42 & 0.005 \\
\hline & Treat $\times$ Leaf age & 1 & 107.879 & 0.13 & 0.714 \\
\hline & Covariate & 1 & 629.053 & 0.78 & 0.378 \\
\hline & Error & 72 & 800.725 & - & - \\
\hline \multicolumn{6}{|l|}{ Fungi (area) } \\
\hline & Treatment & 1 & 1.23595 & 2.76 & 0.101 \\
\hline & Leaf age & 1 & 3.89249 & 8.69 & 0.004 \\
\hline & Treat $\times$ Leaf age & 1 & 1.49607 & 3.34 & 0.072 \\
\hline & Covariate & 1 & 1.79117 & 4.00 & 0.049 \\
\hline & Error & 65 & 0.44776 & - & - \\
\hline \multicolumn{6}{|l|}{ Necrosis (no.) } \\
\hline & Treatment & 1 & 0.005159 & 0.49 & 0.486 \\
\hline & Leaf age & 1 & 0.082073 & 7.77 & 0.006 \\
\hline & Treat $\times$ Leaf age & 1 & 0.000433 & 0.04 & 0.840 \\
\hline & Covariate & 1 & 0.002538 & 0.24 & 0.625 \\
\hline & Error & 65 & 0.010557 & - & - \\
\hline \multicolumn{6}{|l|}{ Necrosis (area) } \\
\hline & Treatment & 1 & 73.665 & 0.09 & 0.761 \\
\hline & Leaf age & 1 & 6920.576 & 8.68 & 0.004 \\
\hline & Treat $\times$ Leaf age & 1 & 104.611 & 0.13 & 0.718 \\
\hline & Covariate & 1 & 627.607 & 0.79 & 0.377 \\
\hline & Error & 72 & 796.906 & - & - \\
\hline
\end{tabular}

leaf herbivory, increase in plant fitness) is necessary. In our study, the beneficial mites (predators and omnivores) as well as several kinds of foliar damage seemingly were not affected by the domatia blockage.

Because coffee is a non-native species, it may have lost mutualistic mites that coevolved in the original habitat (Ethiopia). This process of mutualism breakdown was already reported for several systems (e.g. Klironomos 2003, Ness 2003). We have no information about beneficial mites inhabiting leaf domatia of Coffea plants in their native range but, because indigenous predatory mites use the domatia of exotic C. arabica and benefit from them in southeastern Brazil (Matos et al. 2004, 2006), we discarded the hypothesis of mutualism breakdown in such native-exotic interaction. More probably, the similarity of mite abundance and composition on leaves bearing open and closed domatia was related to space limitation. Studies that have shown evidences of mite-plant mutualisms mediated by leaf domatia reported that domatia entrances were large. For example, Romero $\&$ Benson (2004) observed that the area of domatia apertures in Cupania vernalis Camb. is ca. $1 \mathrm{~mm}^{2}$. Matos et al. (2006), which demonstrated evidences of mutualism between $C$. arabica and predatory mites (I. zuluagai), reported that the diameter of openings in the coffee domatia was $>2 \mathrm{~mm}$, and so large enough to enable the entry of juveniles and adults of predatory mites. In contrast, in our study the mean diameter of domatia entrances was $0.1 \mathrm{~mm}$ ( $\mathrm{n}=36$ domatia from 12 plantlets; range 0.05-0.14 mm), which do not enable passage of the most common mites found on Coffea plants studied here [dorsal shield width of Iphiseiodes sp. varied from 0.19 to $0.36 \mathrm{~mm}(\mathrm{n}=12)$, and of A. herbicolus, from 0.15 to $0.25 \mathrm{~mm}(\mathrm{n}=9)]$. Similarly, in another commercial coffee species, C. canephora, the small and fissure-shaped domatia (see Figure $1 \mathrm{~b}$ in Matos et al. 2006) impede the entry of adult predatory mites (Matos et al. 2006). Besides occurring in mite-domatia interactions, space limitation has also been reported for ant-plant mutualistic interactions (Fonseca 1999, Nishi \& Romero 2008).

Differences in domatia size among C. arabica populations may be explained by differences in C. arabica varieties (but see Aguiar et al. 2004). There are several commercial varieties of this shrub species, and this one we have studied could bear smaller domatia. Unfortunately, we could not discover what is the variety studied here. Alternatively, this is the first study conducted in natural conditions for Coffea arabica shrubs (moderately shaded environments in forest understories; Coste 1992, Shimber et al. 2002). In these conditions plants display optimal photosynthetic rates (Shimber et al. 2002) and might improve plant chemical defenses; thus, they could depend less on biotic defenses mediated by physical structures (i.e., leaf domatia). In contrast, studies that reported evidences of mutualism in mite-coffee domatia interactions (e.g. Matos et al. 2006) have used plants in open areas (traditional coffee plantation), those that had very large domatia entrances; these conditions possibly are suboptimal for coffee plants, which could invest more in biotic defenses (i.e., larger domatia sizes). Moreover, as reported here, predatory mites occurred abundantly on coffee plants, meaning that they might suppress phytophages and indirectly decrease herbivore pressure even on leaves that lack good mutualistic mediators (large domatia); in this sense plant population may have relaxed biotic defenses or even closed domatia to avoid harmful mite entrances (see Romero \& Benson 2004).

Mite exuviae were more frequent inside than outside domatia, suggesting that mites might be using these structures as shelter for molting. Once the populations of the main mite species on $C$. arabica were unaffected by domatia removal, we suggest that these exuviae should belong to the mites in early developing stages, or to tiny mite species. In fact, smaller mites were observed (and counted) inside domatia of coffee shrubs studied here (G.Q. Romero 

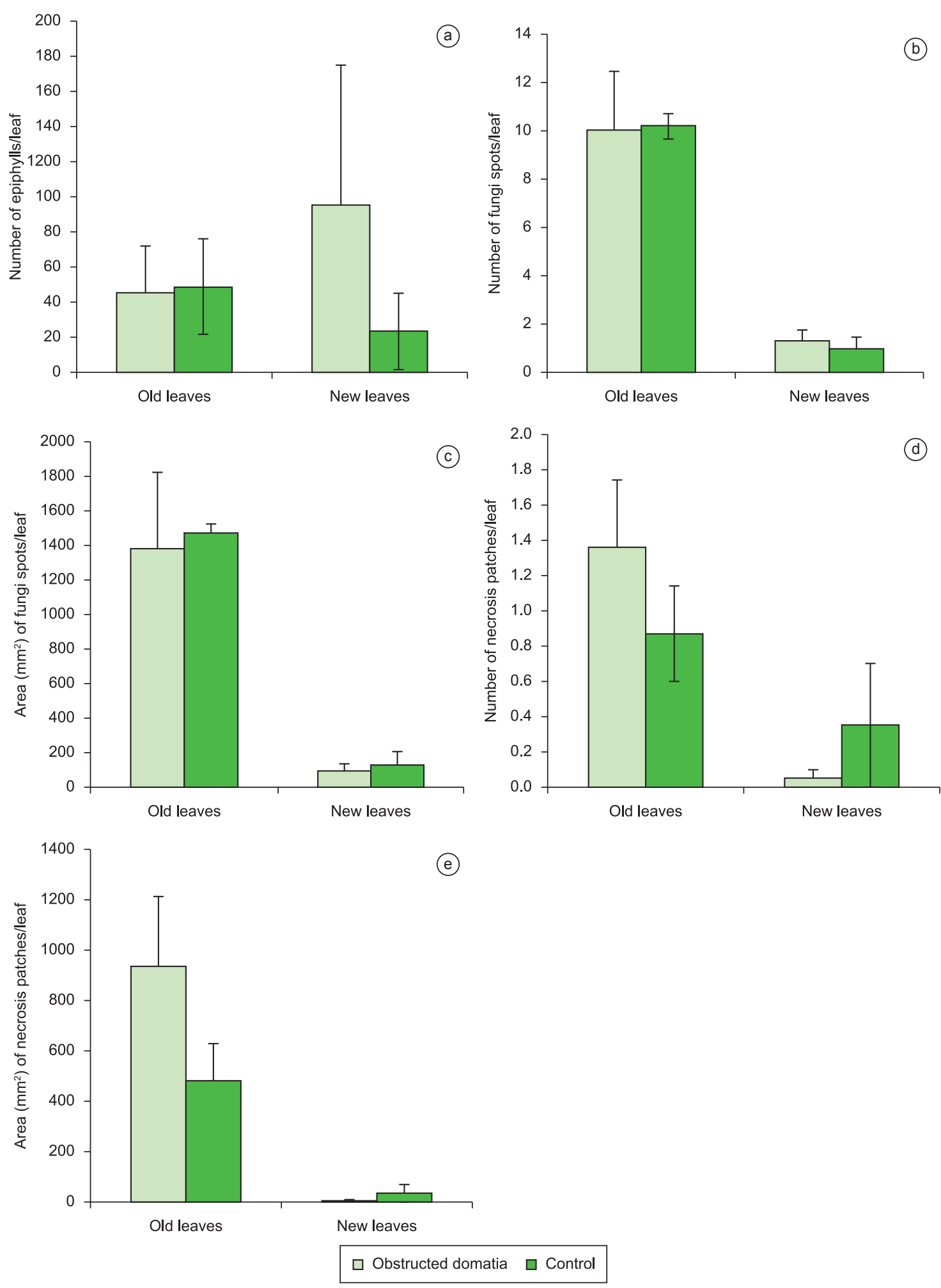

Figure 2. Mean number of a) epiphylls; b) number; c) area of fungal spots; d) number; and e) area of necrotic patches, on old and new leaves that had their domatia obstructed and treated as control. Error bars indicate standard errors.

and co-authors, pers. observ.). Nishida et al. (2005) have found habitat segregation among mites of different sizes (i.e. taxonomic groups), i.e., whereas smaller mites inhabited the smaller domatia of Cinnamomum camphora (L.), an inverse pattern occurred for larger mites, which inhabited larger domatia. Since in our study the most abundant mites were large, differences in mite abundance between treatments were not observed.
Predatory mites (e.g., A. herbicolus, Iphiseiodes sp.) and mite groups that feed primarily on fungi (Oribatida sp.) were more frequent on new than on old leaves. Concerning predators, this vertical distribution could be explained by differences in food resources concentration, as already reported for cassava plants (Onzo et al. 2003). However, prey abundances (i.e. phytophagous mites) were too low either on new and old leaves (see Figure 1), invalidating this 
assumption. In addition, even Oribatida presented similar vertical distribution as predators. Three hypotheses were formulated for this pattern. First, mites may be avoiding senescent leaves, since they are more prone to fall; it should be difficult for a plant mite that fall in the forest ground to return back to its host plant. Second, the newer leaves are more exposed to light, thus could be less cold. Finally, the new leaves (apical) are the most exposed to allochthonous resources that fall from the trees; probably they are those which receive pollen and honeydew released by homopterans living higher on trees. It is known that predatory mites use pollen and nectar from extra-floral nectaries (McMurtry \& Croft 1997).

In conclusion, despite studies have reported associations of beneficial mite with C. arabica domatia (O'Dowd 1994, Matos et al. 2006, Mineiro et al. 2008), our study showed no evidence of the role of leaf domatia on mite-coffee mutualism, i.e., domatia did not increase beneficial mite abundances and, consequently, leaf damages increased on both plants with open or closed domatia. This probably occurred because the entrances of domatia were too small and did not enable their use by phytoseiid mites. Further research should be conducted to investigate the intrinsic (i.e. physiological) and external mechanisms (i.e. selective pressures) involved in domatia size, as well as the influence of domatia size on mite abundances. Finally, the message for coffee farmers is that, besides of coffee production (i.e. amount and quality of grains), varieties of $C$. arabica bearing larger domatia could be preferred instead those with tiny domatia; this will improve beneficial mite permanence, which will potentially decrease plant pests.

\section{Acknowledgements}

The authors thank the staff of the Santa Genebra Municipal Reserve for logistical support in the field. G.Q. Romero was supported by research grants from Fundação de Amparo à Pesquisa do Estado de São Paulo (FAPESP, grant no. 04/13658-5 and 05/51421-0). R.D. Daud and A.T. Salomão were supported by a doctoral fellowship from Coordenação de Aperfeiçoamento de Pessoal de Nível Superior (CAPES), and R.J.F. Feres by Conselho Nacional de Desenvolvimento Científico e Tecnológico (CNPq, nº. 301372/2007-1).

\section{References}

AGRAWAL, A.A., KARBAN, R. \& COLFER, R.G. 2000. How leaf domatia and induced plant resistance affect herbivores, natural enemies and plant performance. Oikos 89:70-80.

BERNACCI, L.C. \& LEITÃO-FILHO, H.F. 1996. Flora fanerogâmica da floresta da Fazenda São Vicente, Campinas, SP. Rev. Bras. Bot. 19(2):149-164.

COSTE, R. 1992. Coffee: the plant and the product. MacMillan Press, London, UK.

FARAJI, F., JANSSEN, A. \& SABELIS, M.W. 2002a. The benefits of clustering eggs: the role of egg predation and larval cannibalism in a predatory mite. Oecologia 131(1): 20-26.

FARAJI, F., JANSSEN, A. \& SABELIS, M.W. 2002b. Oviposition patterns in a predatory mite reduce the risk of egg predation caused by prey. Ecol. Entomol. 27(6):660-664.

FONSECA, C.R. 1999. Amazonian ant-plants interactions and the nesting space limitation hypothesis. J. Trop. Ecol. 15:807-825.

GROMBONE-GUARATINI, M.T. 1999. Dinâmica de uma floresta estacional semidecidual: o banco, a chuva de sementes e o estrato de regeneração. Tese de doutorado, Universidade Estadual de Campinas, Campinas, Brasil.

GROSTAL, P. \& O'DOWD, D.J. 1994. Leaf domatia and abundance and reproduction of mites on Viburnum tinus (Caprifoliaceae). Oecologia 97(3):308-315.
HURLBERT, S.H. 1984. Pseudoreplication and the design of ecological field experiments. Ecol. Monogr. 54(2):187-211.

KLIRONOMOS, J.N. 2003. Variation in plant response to native and exotic arbuscular mycorrhizal fungi. Ecology 84(9):2292-2301.

KRANTZ, G.W. 1978. A manual of acarology. $2^{\text {nd }}$ ed. Oregon State University Book Stores, Corvallis, USA.

LEITÃO-FILHO, H.F. 1995. A vegetação da Reserva de Santa Genebra. Ecologia e preservação de uma floresta tropical urbana (H.F. LeitãoFilho \& P.C. Morellato, org.). Editora da UNICAMP, Campinas, Brazil, p. 19-29.

MARTINS, S.V. \& RODRIGUES, R.R. 2005. Assessing the role of the canopy gap characteristics in the regeneration of shrub and tree species in a semideciduous mesophytic forest in south-eastern Brazil. New research on forest ecosystems (A.R. Burk, ed.). Nova Science Publishers, New York, USA, p. 93-112.

MATOS, C.H.C., PALLINI, A., CHAVES, F.F. \& GALBIATI, C. 2004 Domácias do cafeeiro beneficiam o ácaro predador Iphiseiodes zuluagai Denmark \& Muma (Acari: Phytoseiidae)? Neotrop. Entomol. 33(1):57-63.

MATOS, C.H.C., PALLINI, A., CHAVES, F.F., SCHOEREDER, J.H. \& JANSSEN, A. 2006. Do domatia mediate mutualistic interactions between coffee plants and predatory mites? Entomol. Exper. Appl. 118(3):185-192.

MCMURTRY J.A. \& CROFT, B.A. 1997. Life-styles of phytoseiid mites and their roles in biological control. Ann. Rev. Entomol. 42:291-321.

MELLO, M.H.A., PEDRO JR., M.J., ORTOLANI, A.A. \& ALFONSI, R.R. 1994. Chuva e temperatura: cem anos de observações em Campinas. Instituto Agronômico, Campinas. Boletim Técnico 154.

MINEIRO, J.L.C., SATO, M.E., RAGA, A. \& ARTHUR, V. 2008. Population dynamics of phytophagous and predaceous mites on coffee in Brazil, with emphasis on Brevipalpus phoenicis (Acari: Tenuipalpidae). Exp. Appl. Acarol. 44(4):277-291.

MORAES, G.J. \& FLECHTMANN, C.H.W. 2008. Manual de acarologia: acarologia básica e ácaros de plantas cultivadas no Brasil. Editora Holos, Ribeirão Preto, 288p.

NAKAMURA, T., TANIGUSHI, T. \& MAEDA, E. 2002. Leaf anatomy of Coffea arabica L. with reference to domatia. Jap. J. Crop. Sci. 61(4):642-650.

NESS, J.H. 2003. Contrasting exotic Solenopsis invicta and native Forelius pruinosus ants as mutualists with Catalpa bignonioides, a native plant. Ecol. Entomol. 28(2):247-251.

NISHI, A.H. \& ROMERO, G.Q. 2008. Colonization pattern of Cecropia by Azteca ants: influence of plant ontogeny, environment and host plant choice by queens. Sociobiology 52(2):367-376.

NISHIDA, S., NAIKI, A. \& NISHIDA, T. 2005. Morphological variation in leaf domatia enables coexistence of antagonistic mites in Cinnamomum camphora. Can. J. Bot. 83(1):93-101.

NORTON, A.P., ENGLISH-NOEB, G., GADOURY, D. \& SEEM, R.C. 2000. Mycophagous mites and foliar pathogens: leaf domatia mediate tritrophic interactions in grapes. Ecology 81(2):490-499.

NORTON, A.P., ENGLISH-NOEB, G. \& BELDEN, E. 2001. Host plant manipulation of natural enemies: leaf domatia protect beneficial mites from insect predators. Oecologia 126(4):535-542.

O'DOWD, D.J. 1994. Mite association with the leaf domatia of coffee (Coffea arabica) in North Queensland, Australia. Bull. Entomol. Res. 84:361-366.

O’DOWD, D.J. \& WILLSON, M.F. 1989. Leaf domatia and mites on Australasian plants: ecological and evolutionary implications. Biol. J. Linn. Soc. 37(3):191-236.

ONZO, A., HANNA, R., ZANNOU, I., SABELIS, M.W. \& YANINEK, J.S. 2003. Dynamics of refuge use: diurnal, vertical migration by predatory and herbivorous mites within cassava plants. Oikos 101(1):59-69.

PEMBERTON, R.W. \& TURNER, C.E. 1989. Occurrence of predatory and fungivorous mites in leaf domatia. Am. J. Bot. 76(1):105-112. 
RODA, A., NYROP, J., DICKE, M. \& ENGLISH-LOEB, G. 2000. Trichomes and spider-mite webbing protect predatory mite eggs from intraguild predation. Oecologia 125(3):428-435.

ROMERO, G.Q. \& BENSON, W.W. 2004. Leaf domatia mediate mutualism between mites and tropical tree. Oecologia 140(4):609-616.

ROMERO, G.Q. \& BENSON, W.W. 2005. Biotic interactions of mites, plants and leaf domatia. Cur. Opin. Plant Biol. 8(4):436-440.

SERRÃO, S.M. 2002. Para além dos domínios da mata: uma discussão sobre o processo de preservação da Reserva da Mata Santa Genebra, Campinas SP. Tese de doutorado, Universidade Estadual de Campinas, Campinas, Brasil.
SHIMBER, T., KUFA, T. \& YILMA, A. 2002. The effect of established shade trees on the growth and yield of Arabica coffee in two planting patterns. In International Conference on Coffee Science (ASIC). Trieste, Italy.

VEGA, F.E., OCHOA, R., ASTORGA, C. \& WALTER, D.E. 2007. Mites (Arachnida: Acari) inhabiting coffee domatia: a short review and recent findings from Costa Rica. Internat. J. Acarol. 33(4):291-295.

WALTER, D.E. 1996. Living on leaves: mites, tomenta, and leaf domatia. Ann. Rev. Entomol. 41:101-114.

WALTER, D.E. \& O'DOWD, D.J. 1992. Leaves with domatia have more mites. Ecology 73(4):1514-1518. 